\title{
Research on Model System of Reading Based on Fuzzy Mathematics
}

\author{
Lihua Yang \\ Dongying Vocational College, Dongying, China \\ lihua_yang1@163.com
}

Keywords: model system;fuzzy mathematics; evaluation index; influencing factors; evaluation model; normalization processing; decision coefficient

\begin{abstract}
As an international language, English has received special attention. Universities generally set up various types of English teaching. In the current evaluation system, the selfevaluation is widely used and also is a more important method of formative evaluation; it can have continuous improvement and judgment in the teaching process to more quickly find and solve the problems and get the quality of teaching evaluation. This paper was based on the viewing angle of self-evaluation to analyze the ability of university students in English reading to determine seven self-evaluation index projects, and it was combined with the fuzzy mathematics evaluation method to construct the self-evaluation model system from the angle of internal and external index factors, in order to learn to better understand of their own learning status and guide the universities and all sectors of the community to better carry on the students' English reading teaching.
\end{abstract}

\section{Introduction}

In the process of fast development of current internationalization, the communication of English language has drawn more and more attention, so the universities should pay more attention to the English language teaching. While in the universities English class teaching, the performances and the results of the students need to be fully understood and grasped, in this way it can have the overall and object evaluation of the students learning English. Based on the basic theory of the cognitive constructivism, the autonomous learning is that the students don't need supervision, and through their self-discipline the students mainly have self-learning, actively improve their tasks at the same time, and adjust the ego state and learning progress and so on. So the self-evaluation of the students in English reading ability is based on the whole learning process of students to carry out the overall evaluation, in order to construct evaluation model system, and this can more objectively reflect the situation of the students' self-learning, at the same time it also can better guide the future English teaching activities and effectively direct the universities to carry out the English reading courses and constantly improve the students' English reading ability.

\section{The literature theory}

Self-evaluation is mainly the assessment of the personal thought, behavior and personality, and it embodies the personal self-awareness and the unity of the self-attitude. Self-evaluation is included in the self-consciousness, and it occupies a very important position in each person's personality development.

In order to realize the formative evaluation, it needs the teachers and students to participate in it together and involves the self-evaluation, mutual evaluation and teachers' evaluation and so on; it is mainly to fully arouse the enthusiasm of students to carry out creative learning. In this process the student is learner and also a thinker and partners. And the first two roles need students to have full self-evaluation. It carries out the common combination of internal and external index, and at the same time it must carry on the evaluation of study methods, culture and thinking ability. And in the universities English class teaching, the performances and the results of the students need to be fully understood and grasped, in this way it can have the overall and object evaluation of the students learning English. Based on the basic theory of the cognitive constructivism, the autonomous learning is that the students don't need supervision, and through their self-discipline the students mainly have 
self-learning, actively improve their tasks at the same time, and adjust the ego state and learning progress and so on.

It can take many kinds of ways to have self-evaluation, for example it can make students' learning files, carry on the stage test and class performance evaluation and so on, and it can also study by groups to strengthen students' self-learning and cooperative learning and make progress together.

\section{The ability evaluation model of English reading}

Contents and methods of reading are very important when students learn English reading. So in the process of students learning English the teacher can bring in the self-evaluation theory of English reading ability, that is the fuzzy mathematics theory, and construct the self-evaluation of the English reading ability of university students to have comprehensive evaluation.

At first according to the fuzzy comprehensive evaluation theory the self-evaluation of the English reading ability firstly needs to ensure the evaluation factors, the level of evaluation index factors and the weight value of the index factors. Using fuzzy math method and the membership degree can describe and define the index factors of the influence on the English reading ability to construct the evaluation matrix. The steps of the self-evaluation model mainly are as follows:

(1)Establish the influence index set, evaluation set, and influence index factor weight set of the students' English reading ability

(1) Assume that the influence index set of students' English reading ability is: $A=\left\{A_{1}, A_{2}, \cdots, A_{n}\right\}$

(2) Assume that influence evaluation set of students' English reading ability is: $B=\left\{B_{1}, B_{2}, \cdots, B_{n}\right\}$

(3) Assume that the weight set of influence index factor of students' English reading ability is: $C=\left\{C_{1}, C_{2}, \cdots, C_{n}\right\}$

(2) Establish fuzzy self-evaluation mathematical model of students' English reading ability

(1) Evaluation of the influence single index

The influence index $A_{i}(i=1,2, \cdots, n)$ of the English reading ability can be evaluated according to the evaluation set, the value of evaluation result is: $A \rightarrow\left(t_{i 1}, t_{i 2}, \cdots, t_{i n}\right)$, then fuzzy self-evaluation matrix can be established as the following:

$$
X=\left(t_{i j}\right)_{n \times m}\left[\begin{array}{l}
t_{i 1}, t_{i 2}, \cdots, t_{i n} \\
t_{i 1}, t_{i 2}, \cdots, t_{i n} \\
\cdots, \cdots, \cdots, \cdots \\
t_{i 1}, t_{i 2}, \cdots, t_{i n}
\end{array}\right]
$$

in which, ${ }^{t_{i j}}$ is the proportion of the ${ }^{j}$ evaluation made from the first $i$ influence index factor of students' English reading ability.

(2) Establish fuzzy mathematics numerical transformation

$$
Y=H \times L=\left(y_{1}, y_{2}, \cdots, y_{n}\right), \quad y_{i}=\sum_{i=1}^{n} C_{i} t_{i j}, \quad(j=1,2, \cdots, n)
$$

According to the calculation formula we can have calculation of the comprehensive judgement results. According to the investigation results of university students' English reading ability, the relevant data can be seen in Table 1 .

\begin{tabular}{|c|c|c|c|}
\hline \multicolumn{2}{|c|}{ Project categories of self-evaluation } & $\begin{array}{c}\text { Before the } \\
\text { teachers' guidance }\end{array}$ & After the teachers' guidance \\
\hline \multirow{2}{*}{$\begin{array}{l}\text { Self-evaluation } \\
\text { of English } \\
\text { reading ability }\end{array}$} & Students consciously carry out & 3 & 26 \\
\hline & Teachers' requirement & 30 & 30 \\
\hline \multirow{3}{*}{$\begin{array}{l}\text { Appreciate } \\
\text { degree of learning } \\
\text { to read English }\end{array}$} & Very much & 20 & 23 \\
\hline & General & 7 & 5 \\
\hline & Do not like & 3 & 2 \\
\hline Hope to get & English reading habits and learning methods & 27 & 27 \\
\hline
\end{tabular}

TABLE I. The before and after comparison table of self-evaluation on the English reading ability (30) 


\begin{tabular}{|c|c|c|c|}
\hline $\begin{array}{l}\text { guidance } \\
\text { content }\end{array}$ & After-school tutoring & 22 & 17 \\
\hline \multirow{3}{*}{$\begin{array}{l}\text { Situation of } \\
\text { English reading }\end{array}$} & Daily must read & 19 & 21 \\
\hline & Sometimes read & 7 & 8 \\
\hline & Hardly read & 4 & 1 \\
\hline \multirow{3}{*}{$\begin{array}{l}\text { Completion of } \\
\text { English } \\
\text { Reading } \\
\text { training }\end{array}$} & Students independently complete & 20 & 24 \\
\hline & Occasionally independently complete & 8 & 5 \\
\hline & Occasionally plagiarize & 2 & 1 \\
\hline \multirow{2}{*}{$\begin{array}{l}\text { Preview } \\
\text { situation } \\
\text { of English } \\
\text { reading }\end{array}$} & Daily preview & 19 & 26 \\
\hline & Free to preview & 11 & 4 \\
\hline \multirow{3}{*}{$\begin{array}{l}\text { Conditions } \\
\text { of Learning } \\
\text { to read English } \\
\end{array}$} & Better & 20 & 23 \\
\hline & General & 5 & 5 \\
\hline & Not ideal & 5 & 2 \\
\hline
\end{tabular}

At the same time, according to the self-evaluation and evaluation model formula of student's own English reading ability we can analyze influence degree of the English reading ability index factor and have the self-scoring of each index factor to obtain the weight value of each index, they are shown in Table 2.

TABLE II. Data statistics table of university students' English reading ability self-evaluation index factors

\begin{tabular}{|c|l|l|l|}
\hline \multirow{4}{*}{ Impact indicators } & $\begin{array}{c}\text { Index } \\
\text { weight } \\
\text { coefficient }\end{array}$ & \multicolumn{1}{c|}{$\begin{array}{c}\text { The second } \\
\text { level influence } \\
\text { indexes of model }\end{array}$} & $\begin{array}{c}\text { Model } \\
\text { decision-making } \\
\text { coefficient }\end{array}$ \\
\hline \multirow{4}{*}{ External indicator factors } & \multirow{4}{*}{0.9141} & Degree of consciously reading English & 0.9782 \\
\cline { 3 - 4 } & & The favorite degree of English reading & 0.9262 \\
\cline { 3 - 4 } & & English reading habits & 0.9793 \\
\cline { 3 - 4 } & & Reading Methods & 0.9269 \\
\cline { 3 - 4 } & & Independence of effect completion & 0.9637 \\
\hline \multirow{4}{*}{ Internal indicator factors } & \multirow{4}{*}{0.8927} & Students' foundation level & 0.9828 \\
\cline { 3 - 4 } & & Reading preview & 0.9625 \\
\cline { 3 - 4 } & & Basic achievements of the reading & 0.9527 \\
\cline { 3 - 4 } & & Daily reading frequency & 0.9723 \\
\hline
\end{tabular}

From Table 2 the data statistics Table of university students' English reading ability selfevaluation index factors, it is known that influence factors of students' English reading ability have external index and internal index factors, at the same time; evaluation model also includes many second level influence indexes. External index factors include degree of consciously reading English, the favorite degree of English reading, English reading habits, reading methods, and independence of effect completion. And among these secondary indexes, the greatest influence index is English reading habits, and its decision coefficient is 0.9793; the following is degree of consciously reading English, and the decision coefficient is 0.9782. The least impact is reading methods and its decision coefficient is 0.9269 . The internal index factors not only include students' basic level, reading preview and basic reading performance and the secondary effect indexes of daily reading frequency. Among them, the students' basic level is the greatest influence, the decision coefficient is 0.9828, and the following is daily reading frequency, the decision coefficient is 0.9737 , the last is the reading foundation result, the decision coefficient is 0.9527. External index factors play an important role compared to internal index factors, and the decision coefficient is 0.9141 .

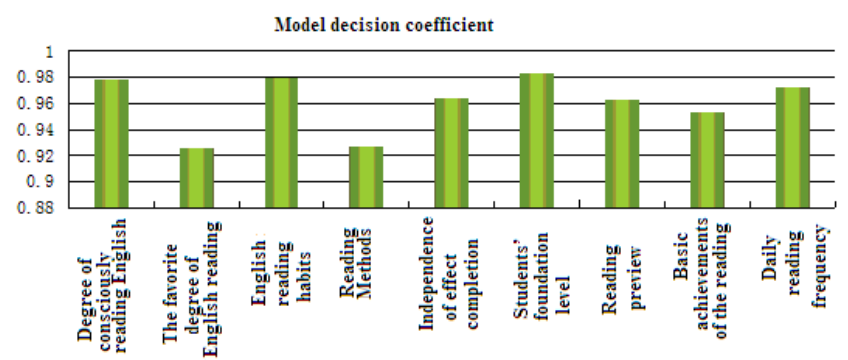

Figure 1. The secondary effect index decision coefficient of the self-evaluation model of university students' English reading ability

From Figure 1,it is known that among the decision coefficients of the model secondary effect indexes there exits some certain differences, it also reflects the different influence degrees of the university students' English reading ability are not identical, they are big or small. And decision coefficients of all kinds of the secondary effect indexes have little difference compared to the 
external index factors, but the reading method decision coefficient of internal index factors is very small, it is the smallest in the internal and external index factors, and it has the least influence on the students’ English reading ability.

\section{The self-evaluation model matrix calculation of students' English reading ability}

According to the influence index factors of the English reading ability, we can select a larger influence indexes s to establish evaluation index set and get:

$F_{\text {reading }}=\left(f_{1}, f_{1}, f_{1}, f_{1}\right)=$ (Consciousness degree, habits,

own foundation, daily reading frequency)

The corresponding evaluation set $\mathrm{W}$ is:

$W=\left(w_{1}, w_{2}, w_{3}, w_{4}\right)$

In which, $\mathrm{W}_{1}$ stands for English level, $\mathrm{W}_{2}$ for reading ability, $\mathrm{W}_{3}$ for reading methods, and $\mathrm{W}_{4}$ for reading Preview.

TABLE III. Evaluation table of the single evaluation factor of English reading ability

\begin{tabular}{|l|l|l|l|l|}
\hline & f1 & f2 & f3 & f4 \\
\hline w & 0.91 & 0.83 & 0.82 & 0.94 \\
\hline
\end{tabular}

Table 3 presents that the matrix set of English reading ability evaluation index factor can be built as:

$\mathrm{T}_{1}=(0.91 、 0.83 、 0.82 、 0.94)$

Accordingly the other evaluation factors indexes are determined to obtain:

$T_{\text {tyas }}=\left[\begin{array}{cccc}0.91 & 0.83 & 0.82 & 0.94 \\ 0.8 & 0.75 & 0.75 & 0.9 \\ 0.9 & 0.8 & 0.8 & 0.85 \\ 0.95 & 0.9 & 0.9 & 0.9\end{array}\right]$

So, the matrix value of reading ability self-evaluation can be achieved.

$\mathrm{B}=\mathrm{A}_{1} \mathrm{~T}=(0.4,0.4,0.3,0.3) \times\left[\begin{array}{cccc}0.91 & 0.83 & 0.82 & 0.94 \\ 0.8 & 0.75 & 0.75 & 0.9 \\ 0.9 & 0.8 & 0.8 & 0.85 \\ 0.95 & 0.9 & 0.9 & 0.9\end{array}\right]$

$=(0.83,0.82,0.811,0.876)$

Then other evaluation indexes can be evaluated, the conclusion is:

$F_{\text {reading }}=\left(f_{1}, f_{2}, f_{3}, f_{4}\right)=$ (Consciousn ess degree, habits,

own foundation, daily reading frequency)

Finally, we have a unitary processing of each factor index and get:

$\mathrm{B}^{\prime}=(0.2023,0.2152,0.2090,0.1950,0.2120)$

This shows that the influence of the students' English reading ability is mainly reflected in the students' reading habits and the times of daily reading. It shows that when they are reading English the reading habits of themselves and connections are important to improve students' reading level.

\section{Conclusion}

In university English teaching, it not only needs the teacher to carry on the classroom teaching, but also needs students to participate in the classes, harmonious teaching atmosphere can make students change their minds and stimulate learning power. And in the current university English teaching, it needs to fully understand and grasp the performance and results of students learning English, in this way it can have the overall objective evaluation of students learning English. Based on the basic theory of the cognitive constructivism, the autonomous learning is that the students don't need supervision, this can strengthen students' self-enthusiasm, enhance confidence, and help to improve the English learning and English reading ability, and the above self-evaluation index projects are improved to effectively guide student's learning, self-evaluation can help students grow up faster. At the same time of having the evaluation, we must carry out self-evaluation, mutual 
evaluation and teacher evaluation these three links, only in this way we can have the objective accuracy of the evaluation and improve the university English teaching quality.

\section{References}

[1] Cai Bingcheng. From the heart and teach people to seek truth - transform English teaching evaluation mechanism to promote the healthy development of students .Overseas English. 2011(01):106-110.

[2] Zhang Yan. Implications of academic self-concept to the junior middle school English teaching .Shanxi science and technology, 2010(06):76-78.

[3] Xiao Liquan. Thinking of English teaching macro model in China.Foreign language teaching,2012(05):51-54.

[4] Zhu Yumei. Reform analysis on university English teaching mode - study on practice case of independent college English curriculum reform . Foreign language and foreign language teaching,2009 (06):23-27

[5] Liu Hailin. Analysis on the training of junior middle school language reading ability .The exam weekly,2011 (4):98-99

[6] Hu Xuewen. Cognitive model of reading the foreign language .Anhui university journal,2012 (02):81-84

[7] Wang Jingling. The schema theory and its application in English reading teaching .Anhui education college journal.2010 (02)

[8] Shao Dan. Exploration of university English classroom interactive teaching mode.Anhui literature,2009 (11):58-62

[9] Tang Xuelian. Under the new situation the exploration of college English class teaching mode. Education technology: development of the new research.Informatization stages, 2009(7):36-39

[10] Yi Qingfang. The application of cooperative learning in English oral teaching .The exam weekly,2010 (43):153-157.

[11] Li Haiqiu, Zhou Ze. Study on University English extracurricular oral English learning system construction .Science and technology information,2009(26):53-57. 